\title{
Quality Assessment of Full-Scale Municipal Wastewater Treatment Plant consisting UASB Reactors and Polishing Ponds during its Start-up Phase in India
}

\author{
NADEEM KHALIL ${ }^{1 *}$ and TARIQUE AHMAD² \\ ${ }^{1}$ Environmental Engineering Group, Department of Civil Engineering, \\ Zakir Husain College of Engineering \& Technology, Aligarh Muslim University, Aligarh 202001, India. \\ 2Department of Civil Engineering, Zakir, AMU, Aligarh India 202001 \\ (Presently - Department of Civil Engineering, Jamia Millia Islamia, New Delhi, India). \\ http://dx.doi.org/10.12944/CWE.11.1.06
}

(Received: November 28, 2015; Accepted: January 02, 2016)

\begin{abstract}
Amongst the technologies available, the upflow anaerobic sludge blanket (UASB) process has been one of the most widely applied methods for municipal wastewater treatment especially in countries of warm climatic conditions like India. However, past about one decade has witnessed rapid decline in the UASB popularity and its implementation. There has been criticism from various sections on the performance of UASB reactors for not complying with the prescribed discharge standards. It is a general hypothesis that the UASB reactors are not meant for diluted wastewater like municipal sewage when typically the BOD is less than $150 \mathrm{mg} / \mathrm{l}, \mathrm{COD} 250 \mathrm{mg} / \mathrm{l}$ and sulphates are more than $150 \mathrm{mg} / \mathrm{l}$. An attempt has been made through this study to investigate the reasons on the basis of quality assessment and field observations on UASB reactors and it's post-treatment of a newly commissioned (start-up) municipal (sewage) wastewater treatment plant commonly called 'STP' having capacity of 14 million litres per day (MLD). Study was aimed to know the gaps during the commissioning stage which could be related to poor removal efficiencies. This paper briefly discusses some issues related to operation and maintenance of the UASB plants with purpose for improvements.
\end{abstract}

Key words: Municipal Sewage, UASB Technology, Final Polishing Ponds, BOD, River Ganga, Pollution Abatement.

\section{INTRODUCTION}

The UASB (Upflow Anaerobic Sludge Blanket Process) Technology, based on anaerobic principles for wastewater treatment, has been widely used across the world, particularly in countries of warm climatic regions like India. It gained popularity because the technology offers moderate capital investments, low O\&M cost, requires no energy for process, easy to implement, fairly good removal efficiencies and mediocre foot print. At present there are about 300 installations worldwide. Amongst the nations which favour UASB for sewage treatment, India, Brazil, Columbia, Indonesia are one of the most leading countries in the world ${ }^{1,2,3,4}$. In India alone, there are about 70 UASB installations for municipal application which are in operation with total flow handling capacity of approximately 3000 MLD (population equivalent 30 million). Indian experience of UASB technology is very diverse and unique.

Like any other anaerobic treatment process, UASB effluent also needs an adequate post-treatment unit to further polish the effluent so 
as to meet the discharge norms for river discharge ${ }^{5}$. In general, polishing ponds based on natural process was being widely used as a secondary step (posttreatment) to further reduce pollutants from the effluent of UASB reactors. Though this combination of treatment removes organic and solid load without any energy input but has its disadvantages as well. The polishing pond occupies large surface area which is giving unpopularity to this combination.

Aiming at monitoring of the plant during the initial phase of start-up and operational issues involved therein, an attempt has been made through this study to investigate the performances of UASB reactors and polishing ponds. The study is based on the quality assessment and field observations of recently commissioned full-scale UASB sewage treatment plant in Northern India. It discusses few

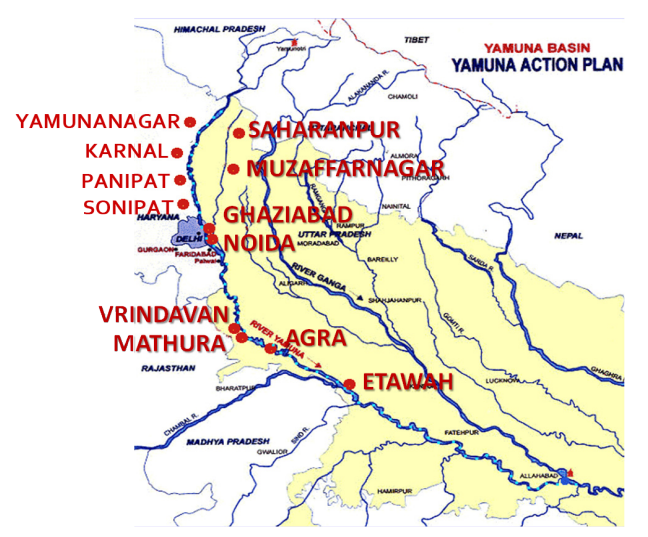

Fig. 1: Yamuna Basin showing cities covered under YAP basic lapses during the commissioning phase due to which not only the UASB reactors but the overall performance of the treatment plant is affected. The outcome of the present work could be useful to understand the fundamental reasons during the initial start-up of UASB reactors that may help to improve the performances.

\section{UASB Technology in India and Operational Issues}

The application of UASB technology in India was triggered after the successful introduction, demonstration and performances of UASB plants under the Ganga Action Plan Phase-I at Kanpur and Mirzapur in early 1990s. Under the Yamuna Action Plan (YAP) ten (10) UASB sewage treatment plants in the province of Haryana and five (05) in Uttar Pradesh (UP) were commissioned in one-go in late 1990s. Figure 1 show a map of Yamuna Basin for places / cities where YAP was implemented.

From that time until 2010, UASB was the most preferable choices of sewage treatment in India. Not only due to good removal efficiencies, the choice was also due to major advantages like no energy requirement, minimal O\&M cost, less sludge production, and resource recovery in the form of biogas for electricity generation. However, during the last six years i.e 2000 onwards, there has been rapid decline in the UASB implementation. This may be attributed to several reasons like poor cases and stories pertaining to performances, lack of willingness to operate properly, negligence on the part of operators and management, lack of technical know-how, resources, motivation, and not realizing

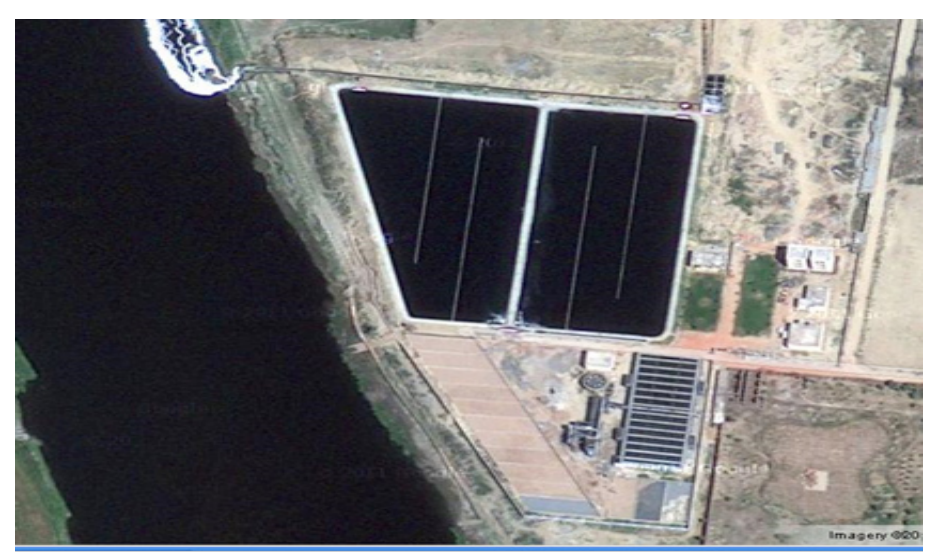

Fig. 2: Satellite Imaginary of the 14 MLD UASB STP at Agra 
the importance of environment or water bodies. It has also been observed that some of the UASB plants are not even commissioned properly and therefore good results are not achieved.

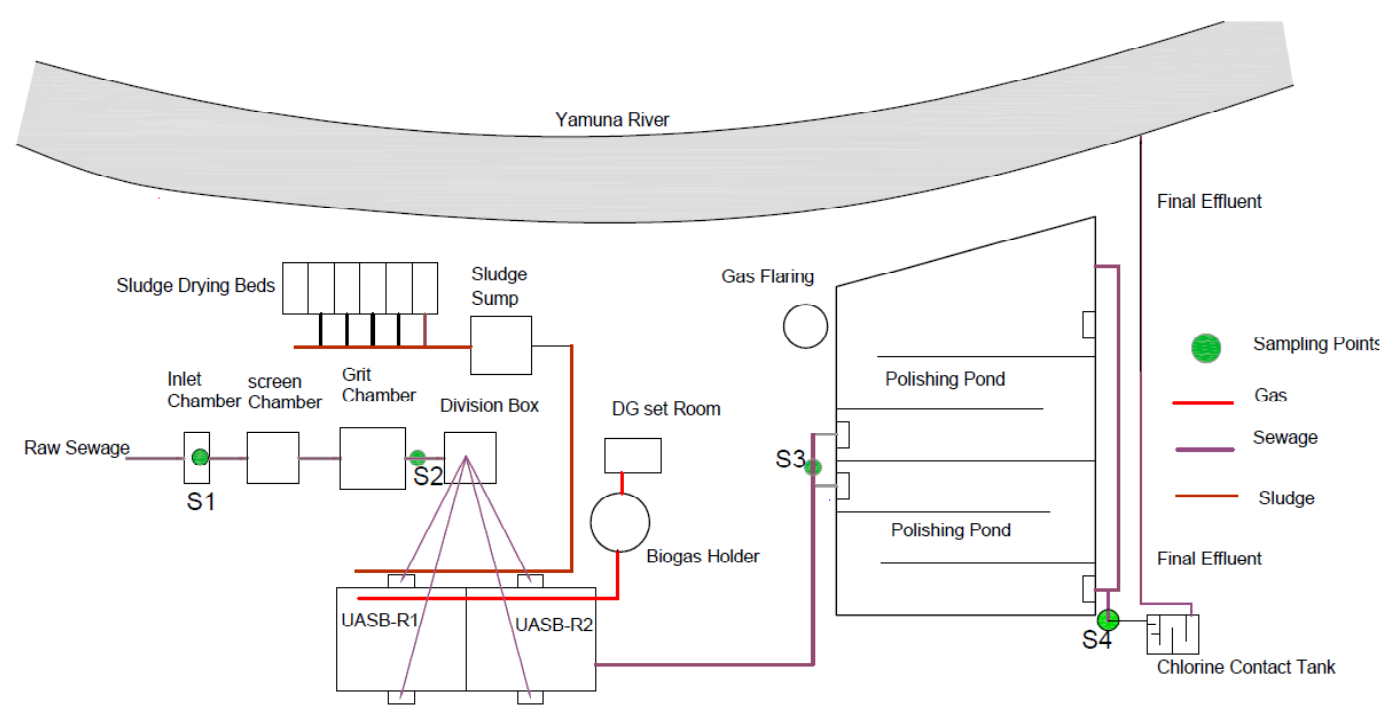

Fig. 3: Layout Plan of 14 MLD UASB STP at Agra
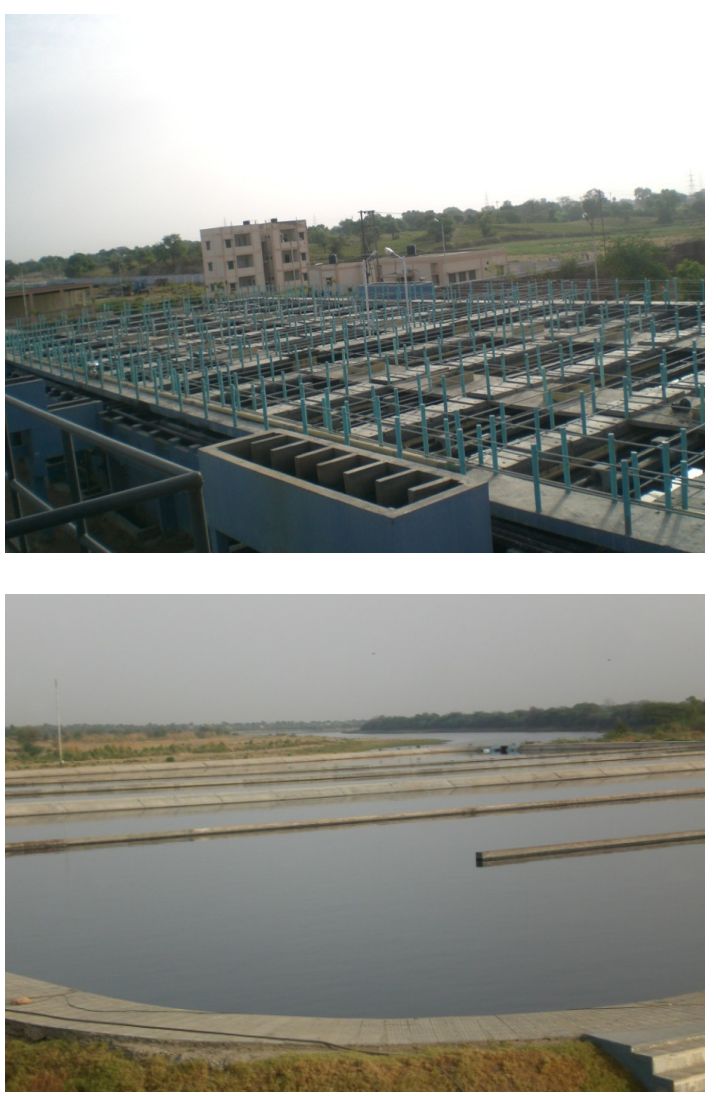

Fig. 4 (a): View of UASB Reactors (b) Final Polishing Ponds

\section{Description of the STP under Study}

The present work was conducted at the recently commissioned 14 MLD UASB Sewage Treatment Plant (STP) based on Upflow Anaerobic Sludge Blanket (UASB) technology at Agra. This STP was designed and constructed under the Yamuna Action Plan with financial assistance (soft loan) from Japan. The STP is located at Village Jaganpur, Dayalbagh, Agra, Uttar Pradesh, India. A satellite imaginary showing the STP and a layout are given in Figures 2\&3.

The raw sewage is pumped to the inlet chamber of the STP from the main pumping station (MPS) which is located at about $3.50 \mathrm{~km}$ at Boodi Ka Nagla, Agra from the STP premises. This STP has two UASB reactors each to handle flow of 7 MLD. Treated effluent is discharged directly into the river Yamuna through the effluent channel, which is flowing adjacent to the STP.

The raw sewage first enters into the inlet chamber and then overflows to the screen chamber through a rectangular notch. After screening, the sewage is passed through mechanical grit chamber and the manual grit channel is kept as standby. The de-gritted sewage is passed through 2 division boxes and split into 4 streams uniformly distributed among 4 distribution boxes, each UASB reactor having 


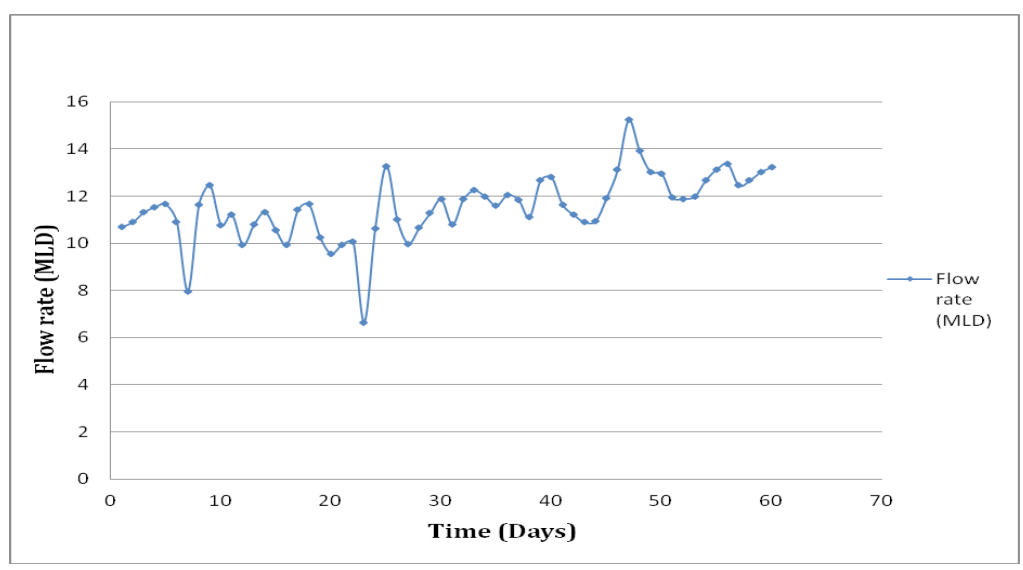

Fig. 5: Record of flow variation at 14 MLD STP

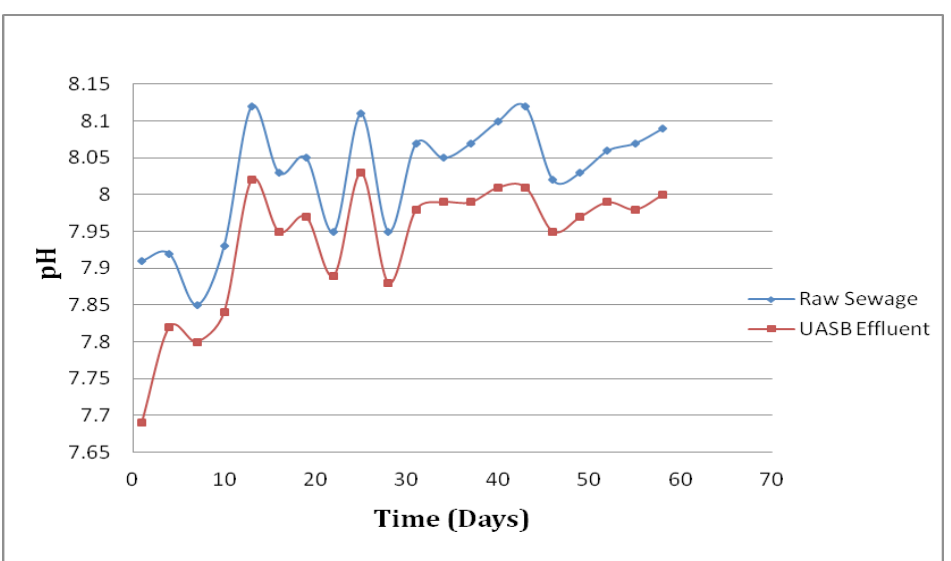

Fig. 6: Variation in $\mathrm{pH}$ in raw sewage and UASB effluent

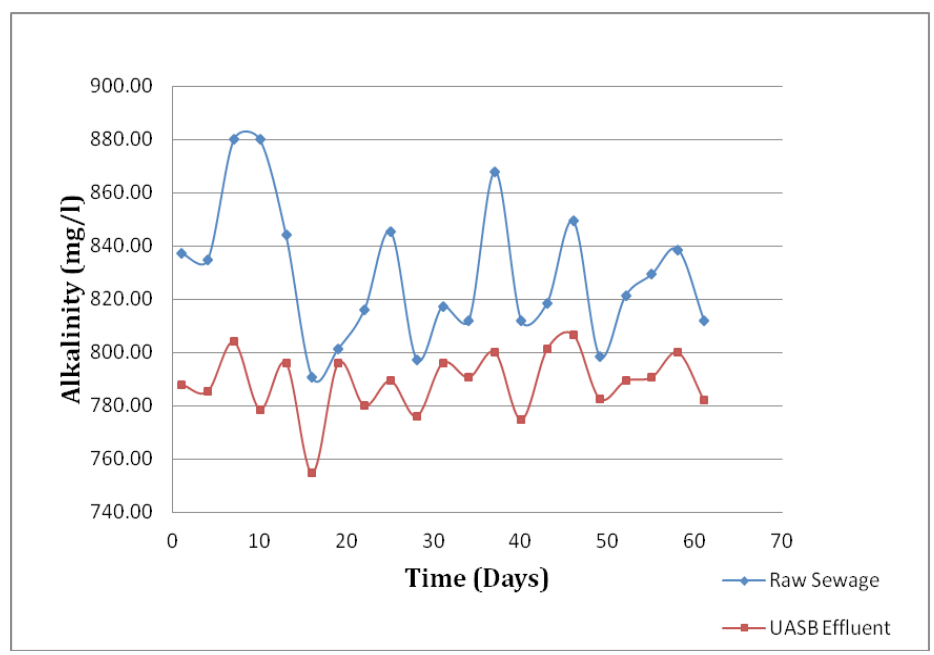

Fig. 7: Variation in Alkalinity 


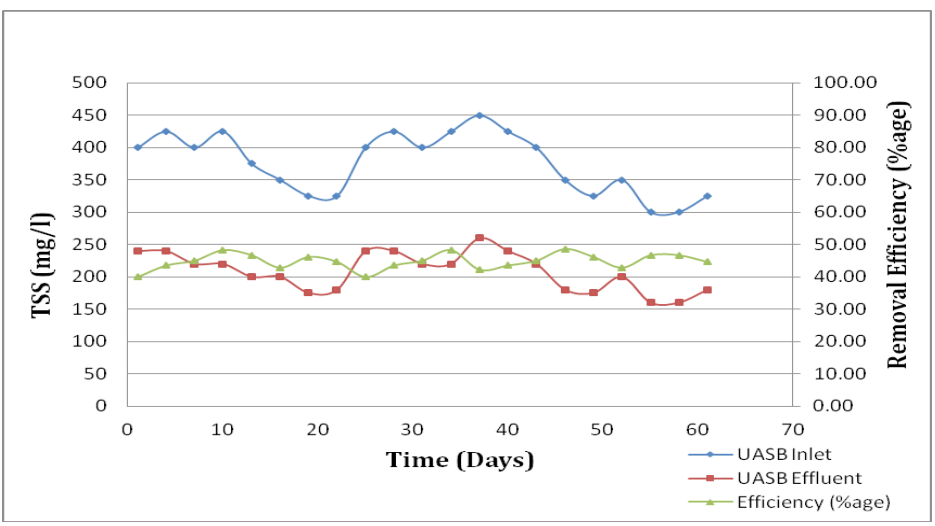

Fig. 8: Time course of TSS

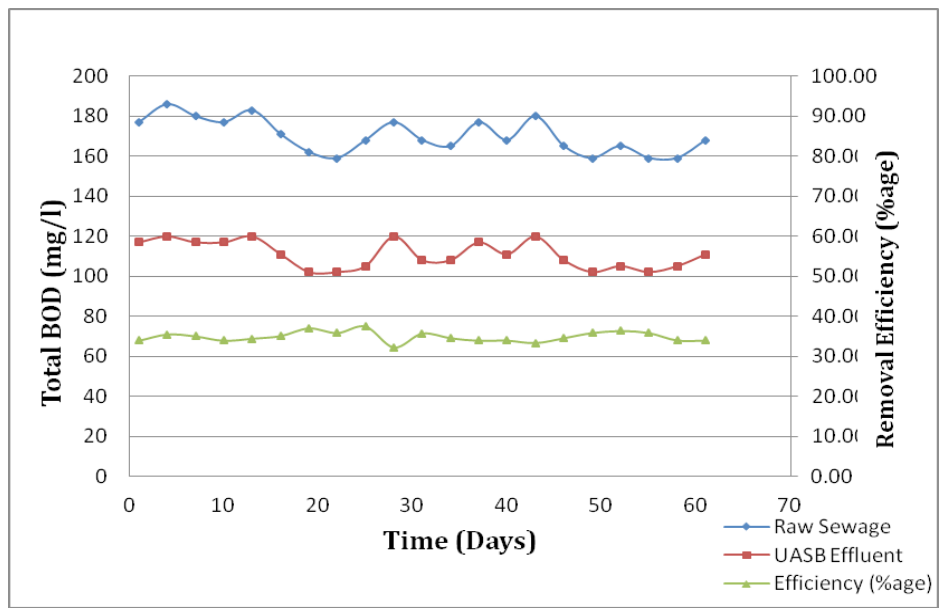

Fig. 9: Time course of BOD

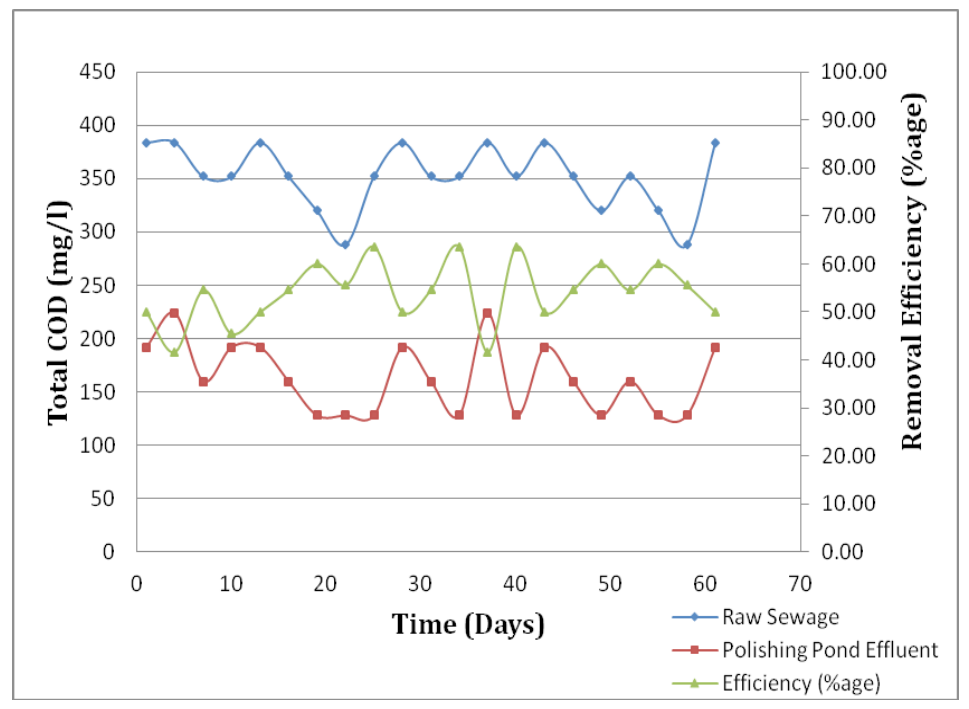

Fig. 10: Time course of COD 
2 distribution boxes on either side. In one reactor there are 16 feeding boxes and each distribution box conveys the wastewater to the 8 feeding boxes which distribute the sewage uniformly over the bed of the reactor through down take pipes. The treated effluent from UASBRs is taken to polishing ponds for further treatment. Ponds are shallow basins having retention time of one day. Finally, the treated effluent from these ponds is chlorinated for pathogen removal in the Chlorine Contact Tank before it is discharges in the river Yamuna, through a $200 \mathrm{~m}$ long concrete channel. A view of 14 MLD UASB reactor and Polishing Ponds is given in Figure 4.

Digested sludge accumulated in the UASB reactor is drained and conveyed directly to the sludge drying beds for dewatering and drying. Biogas produced in the UASB reactor after mist elimination is collected into a biogas holder which has 8 hours gas holding capacity and excess biogas is metered and flared using biogas flaring system. The sizes of different units are given below:
Name of Unit

Inlet Chamber

Screen chamber: Mechanical

Manual

Grit chamber:Mechanical

Manual

UASB reactors

Polishing ponds:FPU-1

FPU-2

Sludge drying beds-I

Sludge drying beds-II

Gas holder tank

Flaring system
No.

1
1
1
2
1
1
11
3
1
1

\section{METHODOLOGY}

Before sampling and analysis, a theoretical framework was developed for taking samples and their analysis for different parameters like $\mathrm{pH}$, alkalinity, BOD, COD, TSS, sulphates, VFA and for

\section{Size / Dimension (LXBXD)}

$3.00 \mathrm{~m} \times 1.00 \mathrm{~m} \times 3.60 \mathrm{~m}$

$3.00 \mathrm{~m} \times 1.20 \mathrm{~m} \times 0.61 \mathrm{~m}$

$3.00 \mathrm{~m} \times 1.20 \mathrm{~m} \times 0.50 \mathrm{~m}$

$5.75 \mathrm{~m} \times 5.75 \mathrm{~m} \times 0.70 \mathrm{~m}$

$20.50 \mathrm{~m} \times 1.60 \mathrm{~m} \times 0.75 \mathrm{~m}$

$28 \mathrm{~m} \times 20 \mathrm{~m} \times 4.70 \mathrm{~m}$

$111.87 \mathrm{~m} \times 50.90 \mathrm{~m} \times 1.25 \mathrm{~m}$

$111.87 \mathrm{~m} \times 50.65 \mathrm{~m} \times 1.25 \mathrm{~m}$

$25.26 \mathrm{~m} \times 8.95 \mathrm{~m}$

$21.00 \mathrm{~m} \times 9.00 \mathrm{~m}$

Internal Diameter $7.00 \mathrm{~m}$ Volume $173.10 \mathrm{~m}^{3}$

Height $6.00 \mathrm{~m}$ sludge (TS, TSS, VSS, Ash Content). Samples were collected from different locations within the STP units. Four different sampling stations/locations, namely, inlet of the STP marked as (S1), grit chamber outlet (S2), UASB reactor outlet (S3) and final outlet of the STP (S4) were selected and are marked in the Figure 3.

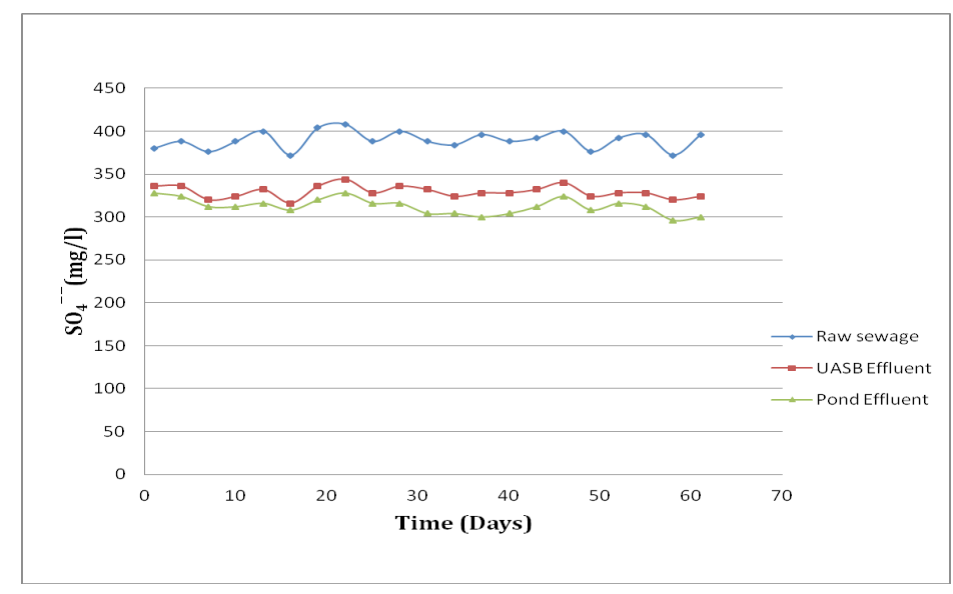

Fig. 11: Time course of sulphates 
Three samples (morning, noon and evening time) on daily basis from each sampling station were collected over a period of about eight months (February to September). These samples were based on "Grab" basis but before their analysis, respective samples were mixed together for testing various parameters like $\mathrm{pH}$, alkalinity, TSS, BOD, COD, sulphates and VFA. Presence of high concentration of sulphates is inhibiting to biological activity. VFA indicates

Another important aspect of this study was to investigate the nature of the sludge of UASB reactors. Sludge samples from different sludge ports in the UASB reactors were also taken once a week. Sludge analysis was done for TS, VSS and Ash Content. All the tests were conducted in accordance with the "Standard Methods for Water and Wastewater Examination"6. The laboratory facility at the STP site and AMU was used for conducting the analysis.

\section{RESULTS}

The summary of data collected from on-site monitoring is presented in Figures 5, 6 7, 8, 9, 10, 11 and in Tables 1, 2, and 3.

\section{DISCUSSION}

The $\mathrm{pH}$ of raw sewage ranges in between 7.85 and 8.12 and that of UASB effluent ranges in between 7.69 and 8.03. The alkalinity of raw sewage was found to be unexpectedly high. It ranges in between 790 and $880 \mathrm{mg} / \mathrm{l}$. The incoming BOD to UASBR varies in between $162 \mathrm{mg} / \mathrm{l}$ and 186mg/l whereas the reactor was designed for average BOD of $250 \mathrm{mg} / \mathrm{l}$. There has been only $30-40 \%$ removal of BOD from the UASB reactors. The total COD in UASB effluent varies between 204 and $252 \mathrm{mg} / \mathrm{l}$ and the removal efficiency of UASBR is very low i.e about $30 \%$. UASBR effluent has TSS value ranging from 219 to $242 \mathrm{mg} / \mathrm{l}$. Generally it is observed that

Table 1: Observed VFA, Alkalinity and pH Values

\begin{tabular}{lcccccc}
\hline $\begin{array}{l}\text { Parameters } \\
\text { ISample No. }\end{array}$ & \multicolumn{2}{c}{ VFA (mg/l) } & \multicolumn{2}{c}{ Alkalinity (mg/l) } & & pH \\
Sewage & $\begin{array}{c}\text { UASB } \\
\text { Effluent }\end{array}$ & Sewage & $\begin{array}{c}\text { UASB } \\
\text { Effluent }\end{array}$ & Sewage & $\begin{array}{c}\text { UASB } \\
\text { Effluent }\end{array}$ \\
\hline 1 & 38.5 & 31 & 788 & 837 & 7.91 & 7.69 \\
2 & 44.0 & 38 & 755 & 791 & 8.03 & 7.95 \\
3 & 46.5 & 31 & 796 & 817 & 8.07 & 7.98 \\
4 & 46.0 & 40 & 807 & 849 & 8.02 & 7.95 \\
5 & 40.6 & 34 & 782 & 812 & 8.04 & 7.02 \\
\hline
\end{tabular}

Table 2: Results of Sludge Analysis (Reactor -1)

\begin{tabular}{lcccc}
\hline Day & $\begin{array}{c}\text { Total } \\
\text { solids } \\
(\mathbf{g} / \mathbf{l})\end{array}$ & $\begin{array}{c}\text { TSS } \\
(\mathbf{g} / \mathbf{l})\end{array}$ & $\begin{array}{c}\text { VSS } \\
(\mathbf{g} / \mathbf{l})\end{array}$ & $\begin{array}{c}\text { Ash } \\
\text { content } \\
\text { (\%age) }\end{array}$ \\
\hline 1 & 170 & 150 & 50 & 66.66 \\
16 & 170 & 120 & 35 & 70.83 \\
31 & 140 & 110 & 30 & 72.72 \\
46 & 165 & 130 & 40 & 69.23 \\
\hline
\end{tabular}

Table 3: Results of Sludge Analysis (Reactor -2)

\begin{tabular}{lcccc}
\hline Day & $\begin{array}{c}\text { Total } \\
\text { solids } \\
(\mathbf{g} / \mathbf{l})\end{array}$ & $\begin{array}{c}\text { TSS } \\
(\mathbf{g} / \mathbf{l})\end{array}$ & $\begin{array}{c}\text { VSS } \\
(\mathbf{g} / \mathbf{l})\end{array}$ & $\begin{array}{c}\text { Ash } \\
\text { content } \\
\text { (\%age) }\end{array}$ \\
\hline 1 & 200 & 140 & 50 & 64.28 \\
16 & 165 & 120 & 40 & 66.66 \\
31 & 255 & 230 & 70 & 69.56 \\
46 & 180 & 140 & 60 & 57.14 \\
\hline
\end{tabular}


when TSS value is high, the COD value is also high. The average TSS removal efficiency of the UASBR is found to be 45 percent. It can be clearly seen that the final effluent from the Polishing Pond does not comply with the discharge standards. TSS concentration varies from 96 to $123 \mathrm{mg} / \mathrm{l}$ which is finally discharged into river Yamuna.

The sulphate concentration in the raw sewage is also unexpectedly very high. The value ranges in between 365 to $410 \mathrm{mg} / \mathrm{l}$. Sulphates are converted into hydrogen sulphide $\left(\mathrm{H}_{2} \mathrm{~S}\right)$ which is readily soluble in water. Presence of sulphide is highly toxic to microorganisms and is a competitor for the consumption of oxygen ${ }^{7}$. The VFA concentration is within the limit but VFA to alkalinity ratio was found disturbed. This low value of VFA/alkalinity ratio is one of the inhibiting factors for degradation of organic compounds in the process of anaerobic digestion.

Sludge data has revealed that there is presence of high concentrations of total solids in the sludge. Irregular drawing of sludge from the reactor has led to the accumulation of solids in the reactor and higher percentage of ash content indicates the presence of inert material which is restricting the biochemical reactions in the reactor. It is observed that higher percentage of inert suspended solids that enter UASB has a direct impact on steady state VSS to TSS ratio in the reactor and ash content to the tune of $60 \%$ is present in the UASB reactors. This indicates that about $40 \%$ active biomass is present which is not good enough to degrade organic matter.

\section{Field Observations and Conclusions} are made:

The following observations and conclusions

i. No trained personnel were found deputed on full-time regular basis for proper monitoring of the newly commissioned treatment facility.

ii. The operation and maintenance manual was not available at the plant site.

iii. The chemist who was deputed had no adequate knowledge of wastewater analysis, particularly of sludge analysis from UASBRs. iv. The laboratory was not equipped with chemicals, glass-ware and instrumentation required for detailed physico-chemical and microbial analysis.

v. The operation of sludge withdrawal was irregular and unplanned. This was one of the main reasons for high concentration of total solids and ash content in the UASBRs.

vi. The screens and grit removal facilities were not working properly. Presence of high ash content in the UASB sludge is one of the reasons of ill-functioning of grit removal facility.

vii. The size of the down-take pipes (HDPE) in the UASB reactors is only $90 \mathrm{~mm}$ which chokes the flow due to presence of floating particles and solids.

viii. Choking of down-take pipes is removed manually by inserting a rod with some force. This damages the HDPE pipe which is never visible from the outside.

ix. Sulphate concentrations in the raw sewage were found extremely high that clearly indicates that prior to technology choice, wastewater survey was not done properly. UASB systems are inhibiting to high concentrations of sulphates.

x. Despite some negligence, the overall performance of the treatment plant during its start-up phase was found good. This indicates that UASBRs can perform much better if proper attention on O\&M is given.

xi. After stabilization, the performance of the plant was found satisfactory but the effluent parameters were not conforming to the prescribed discharge standards as polishing ponds are not able to deliver those values.

xii. New post-treatment alternatives like Extended Aeration System, down-hanging sponged media system (DHS), Constructed Wetlands etc. may be explored, replacing polishing ponds.

\section{ACKNOWLEDGMENT}

Authors are thankful to UP Jal Nigam Agra for permission, providing access to use their lab and accommodation at the plant site during the course of study. 


\section{REFERENCES}

1. Machdar, I., Ohashi, A., Harada, H., Ueki K. A novel and cost-effective Sewage treatment system consisting of UASB pre-treatment and aerobic post-treatment units for developing countries. Water Science \& Technology. 36(12):189-197(1997)

2. Seghezzo L., Zeeman G., van Liel J.B., Hamelers H. V. M, Lettinga G. A Review: The Anaerobic Treatment of Sewage in UASB and EGSB Reactors, Bioresource Technology. 65: 175-190 (1998)

3. Sunny, A., Forrez, I., Lieven, D.K., Haandel, A. V., Verstraete, W. Anaerobic and complementary treatment of domestic sewage in regions with hot climates - A review. Journal of Bioresource Technology. 97: 2225-2241 (2006)
4. Khalil, N., Mittal, A. K., Raghav, A. K., Sinha, R. UASB Technology for Sewage Treatment in India: 20 Years Experience. Environmental Engineering and Management Journal. 5: 1059-1069 (2006)

5. Chernicharo, C. A. L. Post-treatment options for the anaerobic treatment of domestic wastewater. Environmental Science \& Biotechnology. 5: 73-92 (2006)

6. American Public Health Association (APHA). Standard Methods for the Examination of Water and Wastewater. 21st edition (2005)

7. Potivichayanon, S., Pokethitiyook, P., Kruatrachue, M. Hydrogen sulfide removal by a novel fixed-film bioscrubber system. Process Biochemistry. 41(3):708-715 (2006) 